Pratiques et recherches en Centres de langues

\title{
Language centres in higher education: facing the challenge
}

\section{Mary Ruane}

\section{(2) OpenEdition}

1 Journals

Electronic version

URL: https://journals.openedition.org/asp/1127

DOI: $10.4000 /$ asp. 1127

ISBN: 978-2-8218-0394-7

ISSN: 2108-6354

Publisher

Groupe d'étude et de recherche en anglais de spécialité

Printed version

Date of publication: 1 November 2003

Number of pages: 5-20

ISSN: 1246-8185

\section{Electronic reference}

Mary Ruane, "Language centres in higher education: facing the challenge", ASp [Online], 41-42 | 2003, Online since 22 April 2010, connection on 08 December 2022. URL: http://journals.openedition.org/ asp/1127 ; DOI: https://doi.org/10.4000/asp.1127

This text was automatically generated on 29 September 2020 .

All rights reserved 


\title{
Language centres in higher education: facing the challenge
}

\author{
Mary Ruane
}

\section{The wider context}

1 Writing in 1997, Burton Clarke, the renowned world authority on higher education, said "the universities of the world have entered an age of endless turmoil" (Clarke 1997: 291). In recent decades, higher education has undoubtedly undergone significant changes. The impact of new economic and social realities has hit the third-level sector hard. Everywhere there is change and the scale and pace of this change are accelerating. Some of the issues of concern today include the rapid expansion or decline in enrolments, the funding of research, state university relations, the push and pull of the market place, the management of quality and the role of private universities. There is a significant literature in the field of higher education management and a proliferation in the availability of online and print sources. Those working in higher education experience on a daily basis the impact of the changing context and its associated pressures.

2 It is against this complex background that modern and applied linguists have to map the future of their disciplines in higher education, and indeed secure their future. Modern language studies have a long and well-established position in the curricula of higher education. Traditionally, departments teaching modern languages have been able to attract large numbers of motivated students, and they have a distinguished record of research and scholarship. But new challenges have emerged in recent years that are forcing change in the teaching and learning of foreign languages. Student numbers in higher education have increased considerably, the importance of English as a world language has escalated (Crystal 1997, Graddol 1997) and academic and professional mobility has become the norm. University students of all disciplines need practical language competence and higher education institutes accept they must provide an appropriate response to these demands. They must offer skills in English and also in a 
range of European and world languages. As a consequence, the number of non-specialist language students has grown considerably in tertiary education.

3 The scope and scale of the new demands have influenced and, in many cases, profoundly altered the structure of modern foreign language provision in higher education. The development of language centres is one kind of response to the new demands. Although of comparatively recent origin, their numbers have grown considerably in recent years. Although predicting the future is a hazardous activity, it nevertheless seems very likely that the number of language centres will continue to grow. They appear destined to play an important role in language learning in higher education in the first quarter of the twenty-first century.

4 Against this background of change, the decision to devote a special issue of ASp to language centres in higher education is a welcome initiative. It is a timely and valuable opportunity to reflect on their contribution to date and their potential in the future. The overall aim of this paper is to review the past, present and future of language centres in universities. We begin by considering their role, function and trajectory over time. In the second section, we examine some of the characteristics of language centres which have enabled them to professionalise in a relatively short span of time. As they face the future, we examine some of the major challenges which confront them in terms of planning and development. Finally there is a brief review of two important language centre initiatives in second language pedagogy.

\section{Role and function of language centres}

The structure and organisation of language centres in higher education tend to reflect the environment, history and context in which they have evolved. Faced with large increases in demand for language services, universities have identified and implemented a range of responses to new needs. A minimalist description of the function of a language centre is that it should provide language education and training for non-specialist students, i.e. students not studying philology or specialising in literary, cultural or linguistic studies. A very large number of further and higher education colleges in Europe now list a 'language centre' as a core academic unit within their institutions. But language centres can differ considerably in their aims, activities and resources. Sometimes, an institution can have more than one language centre, each serving a different function, whether teaching, research, technical support or other.

Issues such as the role, function and scope of language centres were on the agenda of a group of likeminded modern and applied linguists who came together at the University of Florence in 1990 to discuss the future of language learning in higher education (AubBuscher \& Bickerton 2002: 206). The group included representatives of national associations of language centres or institutes in higher education from a number of European countries.

7 They wished to consider the feasibility of establishing a European umbrella body that would represent language centre interests in higher education. In the course of their discussions, it became clear that new kinds of language learning needs had emerged across European higher education, and had expanded rapidly throughout the eighties. It was also evident that the pedagogic and organisational solutions being developed by universities in response to the new needs had much in common. Despite the similar 
nature of the activities, the term 'language centre' was not widely used or recognised in higher education at that stage. On the contrary, there was a wide variety of designations such as language institute, language unit, language teaching centre, institution of foreign language study, language services, language laboratory and many others After much deliberation, the group agreed to fix on the term 'language centre' to describe an appropriate place and environment where a certain approach to language learning and research would be implemented. In line with changes in organisational structures in higher education in the latter years of the twentieth century, the designation 'centre' was increasingly used alongside terms such as department or institute. It suggests interdisciplinarity as well as diversity of function, from the purely academic to the practical or applied. It also suggests flexible and adaptable organisational models to support a range and variety of teaching and research functions. The use of the term 'language centre' in higher education spread quite rapidly to a point that today it is used as a generic label in much the same way as the library, computer or multi-media centre.

Having agreed on the value of associative activity, the meeting in Florence also agreed to create a confederate structure which would bring together national associations of language centres. This was the European Confederation of Language Centres in Higher Education or Cercles (2002: 206). Most importantly for the future of language learning, they reached consensus on the core functions of a language centre. They agreed "that there were three types of activity common to all language centres, whatever their name or institution framework and however diverse their missions" (2002: 206). These were:

- - practical language training especially for learners not specialising in languages,

- - the use of appropriate technology for language learning,

- - research and development in the field of language teaching and learning.

9 In the case of the first of these activities, the assumption was that a language centre should be focussed on the ideals of communicative competence (Hymes 1974). Secondly, the use of technology, no matter how minimal, was central to the delivery of programmes and courses to meet the demands of a new type of student. With regard to the third function, the founding group clearly underlined the importance of research in the mission of language centres. They should make a specific contribution to the development of research in language learning. A strong research agenda and profile were also important to ensure the status and standing of language centres in universities. This issue of research is central and it is one to which we will return later.

\section{Language centres over time}

10 In this section, we consider briefly some of key developments that have led to the shaping of language centres, as we know them today.

11 Whilst language laboratories should not be considered as exact precursors of language centres, their development had an impact on the way centres were to develop. From the outset, the importance of and need for cutting edge technology was emphasised by those working towards the improvement of language learning. The language laboratory, developed in the fifties and sixties, was the first tangible outcome of this effort. To this day, it remains a term well-known by the wider public. This period laid the foundations for the strong technical emphasis in language centres. Their stock in trade in the early years was audio recorders to which were added video recorders, satellite television and 
then later computers (Jones 1997). It is worth noting that many distinguished directors of language centres began their careers as managers or heads of language laboratories.

However, it is generally believed that university language centres in their present form came into being during the sixties and early seventies (Aub-Buscher \& Bickerton 2002, Cormeraie \& Vogel 1996, Esch 1999). This was a period of considerable growth and confidence in language learning, a period when it was believed that:

greater knowledge and understanding of language and language learning would more or less unproblematically inform educational change and improvement. (Mitchell 1996: 7)

13 The importance of applied linguistics, second language acquisition and other related fields of study emerged and contributed to a general understanding and growing insight into the ways languages were taught and learned. Many significant events in language teaching date from this period. Some of these include the emergence of the communicative approach to language teaching (Munby 1978), the publication in 1975 of the Threshold Level (Van Ek 1975), the development of Languages for Special Purposes (Dudley-Evans and St John 1998, Hutchinson and Waters 1987), and the early stages of computer assisted language learning.

demand for languages grew, it was clear that there was a need for different kinds of teaching and specialist facilities for non-specialist language students. The concept of the language centre began to emerge, slowly at first and then with increasing momentum. In the early stages however, language centres were small, uncertain of their role and they played a very limited role in the life of the university. The notion of the 'language centre' did not find its way quickly into the specialist language learning literature. For example, A.P.R. Howatt's comprehensive history of English language teaching does not deal with language centres, and the term 'language centre' is not even in listed in the index (Howatt 1984).

By the nineties, much had changed. The collapse of the Soviet Union and the ensuing political shifts had many impacts. Greater European integration was an increasing force. The role of technology - from computer assisted language learning to the internet - had opened up undreamt of possibilities in communication and learning. As the forces of globalisation took root, language learning needs grew - particularly in English (Crystal 1997, Graddol 1997). But increased demand for language learning brought many problems in its wake. Large numbers of students had to be taught in at times very unsatisfactory conditions. There were increasing questions about effectiveness and quality of delivery. The demand for large scale testing had grown and with it the explosion in the 'language testing industry'.

16 The nineties also heralded changes in second language pedagogy. It was becoming clear that the development of effective models for second and foreign language learning was a more complex and challenging task than it may have seemed during an earlier period. Disenchantment with approaches to second language teaching at the time are evident in the following statement by Alastair Pennycook:

One of the problems with applied linguistics [...] has been its divorce from educational theory and the tendency to deal with language teaching as a predominantly psycholinguistic phenomenon isolated from its social cultural and educational contexts. (Pennycook 1994: 299)

For further evidence of a growing awareness of the need to re-question some basic issues in second language pedagogy during the nineties, the reader is referred to a range of 
articles in a 1997 issue of the Modern Language Journal. An overview of the issues involved is provided, and the leading article makes a strong case for a re-conceptualisation of SLA (second language acquisition) which has "firmly established interests in matters of language education and pedagogy" (Firth \& Wagner 1997: 296). It is argued that this reconceptualisation is needed in order to ensure that SLA can "become a richer and more robust enterprise, better able to explicate the processes of second and foreign language (S/FL) acquisition" (1997: 285).

Thus, language centres in the nineties found themselves in a challenging situation. As well as a raft of socio-political changes, there were reduced levels of university funding, growing numbers of students and a changing context in second language pedagogy. Against this background, language centres were expected to implement large-scale programme development, syllabus design, language for special purposes, testing and technology research.

19 Far from abating, the pace of change continues to accelerate today. Referring to the development of language learning in their recent report Michael Kelly and Diana Jones concluded that "far-reaching changes have taken place for the past few years, and a new landscape for languages is emerging from these changes" (Kelly \& Jones 2003: 2). Whilst the demand for large-scale language training still grows, the context is changing. Many European universities are experiencing shifting patterns in student enrolments and resource constraints have begun to bite. The research and teaching functions are frequently now in competition for funding allocations. In the field of language learning, third-level institutions are casting round for more cost-effective solutions to problems of provision. As the push and pull of the market place continues, alternative suppliers of language teaching services are emerging. These include private sector provision, public and private partnerships, outsourcing, more widespread self-access, on-line teaching and others, to provide cheaper and more effective solutions. Whilst the 'deschooling' of languages may not be imminent, the context for language learning is once again changing. Language centres have clearly a role to play in shaping this evolving situation for the benefit of language learning.

\section{Enabling features of language centres}

20 In their history of the first decade of Cercles, Aub-Buscher and Bickerton wrote that the founders of language centres

[...] sought to disengage the teaching of practical language skills from that of philology or literature and language learning was no longer viewed as the sole preserve of specialist linguists or future language teachers. (Aub-Buscher \& Bickerton 2002: 205)

21 But how did the creators of language centres succeed in developing an alternative environment in institutions of higher education? And what can language centres today learn from the efforts of their antecedents? In her keynote address to the Cercles international conference in Bergamo in 1998, Edith Esch summed up the strengths and capacities of the early pioneers in language centres:

En Europe depuis les années 60, ils ont joué le rôle d'éclaireurs en s'engageant dans la formation de nouveaux publics et en remettant en question la nature de la relation pédagogique traditionnelle ainsi que celle des contenus d'enseignement et des savoirfaire (Esch 1999: 11) 
According to Esch, language centres were successful because they were able to discern the nature and scope of emerging demands, develop creative responses to new problems, and then devise successful implementation schemes. To do this, they had to focus on a wide range of issues that were not alone pedagogic, but also strategic and managerial. In the following section, we review a number of these including governance, staffing, use of technology and collaborative networks.

\subsection{Governance} pointed out, new needs in language teaching and learning have led to a repositioning and a re-conceptualisation of the language teacher's role (Mozzon-McPherson 2001: 7). Notwithstanding the growing importance of technology, it is generally recognised that language learning remains a labour-intensive field and that successful management of the human capital dimension is critical for success. It is through effective human resources that all other functions in language centres - finance, programmes, materials, planning - are handled.

27 To create new programmes and meet the needs of new groups, language centres had to develop new approaches to the deployment and development of their staff. One of the biggest changes to occur was with respect to the role of the teacher. It is generally 
accepted that the generic term 'language teaching' now covers a range of many different and complex activities.

This includes functions and roles such as those of researchers, advisors, technicians, counsellors, software developers, multi-media operators, mentors, events managers and many others (Mozzon-McPherson 2001: 7). The training and development of these different staff-groups, and their organisation into effective multi-tasking and multidisciplinary teams were major factors in the successful development of language centres. The interpersonal, educational, administrative and technical skills of these staff are considerable. The fact that employees of language centres make the transition so easily into areas such as management, quality assurance, technology in education, open and distance learning, academic administration, communications and many other areas is ample evidence of this.

\subsection{Specialist technology and space}

The use of cutting edge technology has always been critical to the advancement of language learning. As stated earlier, it played a particular role in the development of language centres in the early years.

But the traditional unit of the language laboratory, which incorporated a variety of video and audio laboratory facilities, had to make way for a newer and more sophisticated technological infrastructure. The language laboratory has been replaced by large and complex facilities requiring specialist personnel, programmes and often, large budgets. Great progress was initially made in investigating and developing technology systems suited to the language centre environment, including CALL and web-based language teaching. Later came the growth of self-access systems to which language centres made a significant contribution.

importance of self-access cannot be overestimated, and as David Little has written "[...] has been the single most important development affecting the learning of foreign languages around the world" (Little 2001: 30).

But in more recent years, it has become clear that language centres do best when they have dedicated and purpose-designed space. This facilitates the integration of language learning functions and provides specialist facilities not just in technology, but also in classrooms, libraries, teacher preparation areas, student consultation spaces, relaxation areas, etc. The task of conceptualising, shaping and creating purpose-designed units has challenged not just those who work in language centres but also architects, designers, engineers and others who have to create and build them. Diverse functions had to be incorporated, space had to be maximised, interaction optimised and different work areas integrated. And this task was effectively achieved. The difference between the early language centres - very often poorly refurbished spaces which were not very userfriendly - and more recent examples of highly sophisticated, modern language centres with an emphasis on integrated technology, interaction, ease of access, aesthetics and comfort, is considerable.

\subsection{The potential of collaborative networks}

The enormous potential of networks was tapped from an early stage by language centres. They recognised the importance of establishing links and relationships amongst 
individuals and groups, but especially across institutional and geographical boundaries. Networks of language centres were created regionally, nationally, at a European and, more recently, global level.

The benefits that accrued from collaborative and participative environments were critical for the advancement of language centres. The advantages included increased exchanges of information and contact among centres, the optimising of language training to make it more cost-effective, the establishment of agreed codes of good practice, and extensive cooperation in research and development. Links were established amongst language centres themselves and with a wide variety of other language and non-language learning organisations including INGOs (international non-governmental organisations), governments, and national as well as local communities.

The first association of language centres in European higher education was the Arbeitskreis der Sprachzentren, Sprachlehrinstitute, und Fremdspracheninstitute (AKS) in Germany. Established in 1970, it now numbers almost 120 universities as members. As stated on its website, it is the only association in Germany that comprehensively represents the field of foreign language teaching in higher education. In its early years it focussed on establishing a strong organisational infrastructure. But from the late seventies onwards, it began to emphasize research and scholarly publication on the one hand, and strategic action on the other. It publishes extensive reports and surveys and acts as an interlocutor for government. And as we shall see later, it initiates and organises a major programme of accreditation of language competence.

The drive to work associatively also developed elsewhere in Europe. After significant expansion during the seventies, directors of Language Centres in the UK and Ireland began to meet regularly from 1981 onwards. Support staff in UK universities also came together around this time and soon established their own association. Both organisations developed in parallel for many years and then agreed to form one large and important body representing a wide range of language learning interests. The new body is called AULC, the Association of University Language Centres in the UK and Ireland, and was established in 1998.

Italian language centres began to meet in the early nineties. As was the case in the UK, the first association formed in Italy brought together the senior managers of language centres only. Membership was not open to all staff. The first organisation was called the Conferenza Permanente dei Presidenti e Direttori dei Centri Linguistici Universitari Italiani. But in May 1997 in Bari, AICLU, the Associazione Italiana dei Centri Linguistici Universitari, grouping all staff working in language centres, was born. Today, the Italian association is one of the most active in Europe. University language centres have expanded rapidly as a result of the recently introduced obligatory foreign language requirement for all Italian undergraduates.

The first founding statutes of the French national association, RANACLES (Rassemblement National des Centres de Langues de l'Enseignement Supérieur), date from 1992 and name an executive committee under the chairmanship of Professor Michel Perrin (Aub-Buscher \& Bickerton 2002: 213). As well as an important national role, the French association was particularly active in developing a federal structure at European level. The founding conference of the European confederation, CercleS, was in fact held in France in Bordeaux in 1992 and focussed on the meaning and role of language centres: Des Centres de langues dans l'Enseignement supérieur : Pour quoi faire? Pour y faire quoi ? (Perrin 1993). 

many challenges. They have to navigate an uncertain future as higher education enters a new phase. Undoubtedly, the environment within which they find themselves generates some of the challenges they face. But they can also exercise control over many of their spheres of activity.

\subsection{Relations with the institution}

In the keynote address to the CercleS conference in Dresden in 1996, Hans Joachim Meyer talked about "the misconception of the function of language teaching in academic education and consequently of the function of language centres at universities" (Meyer 1997: 6). In the same address, he referred to language centres as "the unloved poor cousin" among their departments who frequently find themselves under the "tutelage of the philologies" (Meyer 1997: 10-11). Whilst this remark may not be as apt today as heretofore, it nevertheless highlights the issue of status. A common complaint of many staff working in language centres is that their work is perceived to be peripheral to the main business of language teaching in the university. Tension between them and philological departments is not uncommon and, for reasons of academic structure, they often lack control over their decision-making and their activities. Language centres 
should not end up being "an appendix or an extension of philological departments, nor should they be considered exclusively as services departments" (Meyer 1997: 11). centrated earlier, the development of research was considered by the founders to be a central part of the mission of language centres in higher education. But many language centres face difficulty in this area and are not as research active as they should or could be. In many cases, the reasons are linked to availability of resources and David Little has referred to the "deplorable reality where many language centres have been set up in such a way that it is all but impossible for their staff to engage in research" (Little 1999: 11). But the research function is crucial as Hans Joachim Meyer has pointed out: But language centres can learn from the past. Their institutional position today has striking parallels with an earlier era. A hundred and fifty years ago, modern language studies were the poor relation. They were on the outside trying to break into an educational system that had been dominated by Latin and Greek since the Middle Ages. Learning to speak a foreign language was seen as an activity subordinate to other fields of study (the classics, theology or mathematics) and considered mainly as an accomplishment for those wishing to travel abroad for leisure or commerce. As Howatt has explained 'the process whereby modern languages 'infiltrated' the traditional preserves of the classics varied from one country to another but it was a tough struggle everywhere" (Howatt 1984: 129). The challenge was considerable as the defenders of classical languages "did not give in easily to the claims of living languages that 'anybody' could learn" (1984: 129).

$$
\text { But the research function is crucial as Hans Joachim Meyer has pointed out: }
$$


Taking the concept of a language centre seriously means combining linguistic findings relevant to academic communication and its various genres with pedagogical insights derived from and applicable to the various categories of learners in an academic context, to form an integrated approach that treats the learners as candidates for or members of the international scientific community. (Meyer 1997: 11) made. in the future. budgets.

As regards the research agenda which can and should be pursued by language centres, it is worth once again quoting David Little when he writes: "at a time when much second language acquisition research prides itself on its lack of interest in pedagogical matters, there is an acute need for research that draws on the findings of independent work in linguistics and psychology to explore the processes of language learning in specific contexts and for a wide variety of academic purposes." (Little 1999: 6) It is clear from this that there is no shortage of topics and areas for research to which language centres can actively contribute, in such areas as Languages for Special Purposes (LSP) and Languages for Academic Purposes (LAP), curriculum development, testing, methodology, autonomous learning, technology-based learning and many others.

As well as identifying the research agenda, there is a need for language centres to take a more structured approach to creating the appropriate conditions for research in the language centre environment. There are, it is true, many opportunities to hold national and international events at which presentations of research and academic papers can be

But funding sources for the development and management of medium- to large-scale research projects is critical. Language centres need to seek alliances and partnerships. They cater for an enormous student constituency, span many countries and languages and are made up of many different categories of staff. Not surprisingly, therefore, they have the potential to be a significant partner in a range of European and international language teaching projects. This is a potentially important source which should be tapped

\subsection{Language centre management and planning}

Whilst a planned and structured approach to issues of resourcing, management and outcomes is deemed essential in many spheres of life, it has not as yet been much applied to language learning. Fields such as health, education, the arts, transport and the environment - to name but a few - are examples of areas where the need for careful planning and sustainable development is generally accepted. Whilst there are signs that language policy and planning issues are at last becoming recognised as important fields of enquiry, it has been a slow process.

Yet questions about effective forms of governance are high on the agenda of universities today. Language centres deal with complex logistical issues, and they manage large

They have to be able to demonstrate that they can manage their affairs effectively, and optimise resources. But there has been a limited emphasis on management structures which has hindered the focus on continuing improvement and effective governance in language centres up until now. Fundamental appraisals of structures are needed as is guidance from human resource professionals working in similar fields. An important way forward is the setting in place of accreditation and quality control systems. 

availability of empirical data. The general absence of published material on language education management is striking. And there is little documentation on what happens in language centres and on the range of activities in which they are engaged (Ruane 2002). There is a need to assemble more descriptive data about their workings in a variety of contexts. Universities too should provide more opportunities for education and development in this field. They need to increase the range of postgraduate courses in language education and project management at diploma, masters or doctoral levels. The future of language centres will depend considerably on the quality of its staff, particularly those in senior positions.

\subsection{Accreditation}

It has been evident for some time that the introduction of some form of accreditation system for language centres in European higher education is long overdue. Such models exist for a wide range of professional, scientific and educational sectors including business schools, engineering institutes, hospitals or other such bodies.

While language centres are acutely aware of the need for such a system (Voss 1996, Voss 1997), progress has been slow. Present day constraints in financing may be a hindrance. But if language centres are wise, they will not delay too long. They will themselves take on the responsibility of controlling and managing the evaluation systems, and for regulating their activities. This is the best way of producing an effective, constructive and change-oriented scheme of accreditation.

58 Language centres in higher education already have a significant record of achievement in effectively measuring quality across a range of areas. These include levels of proficiency, programme effectiveness and materials production. But the approach taken to quality assurance and accreditation will need to be more ambitious and broadly-based if it is to meet today's needs in the area of evaluation as outlined by Christopher Candlin:

[...] evaluation can be directed at a range of objects in the domain of language education; at planning and policy decision-making, at programmes, products, resources, activities, participants and their interactions, curricula and at the organisational structures themselves within which the evaluation takes place. (Candlin 1998: xvi)

Devising models of a 'whole institution' or 'institution-wide' approach to accreditation, which will assess all aspects of the operation of a language centre in an integrated way, would represent a significant but worthwhile challenge for language centres. The scheme should also be simple to run and cost-effective. Experience from elsewhere shows that heavy investment in elaborate systems of quality assurance and improvement do not necessarily pay off in the longer term.

\subsection{Improved resourcing}

We end this review of the challenges facing language centres by considering the issue of financial resourcing. As an innovative sector doing groundbreaking work in research and development, whilst at the same time catering for the language needs of large numbers of students, language centres represent, by any standard, highly cost-effective and 'value for money' units in higher education. 
61 But it appears that they have difficulty getting the credit or recognition for the important work they do, and for the large-scale services and efficiencies they provide. And regrettably, the innovative work on language learning undertaken in language centres has not always been linked to improvement in the conditions of work for those involved. On the contrary, language centres are very often seen as the means to make cost savings, to generate revenue and control finances. More is expected for less. And resource allocation models adopted by universities do not always work to the advantages of language centres. Ways must be found to demonstrate the extent of the achievements of language centres, and to make the case for greater resources.

\section{Areas of achievement}

62 In this final section, we feature two significant and highly successful projects developed by language centres in higher education, and which are making a significant contribution to the discipline of language learning. The first is a major testing initiative developed by language centres in Germany. The second project concerns the role of Cercles in the development of the European Language Portfolio, one of the most important developments in language learning in recent years.

\subsection{Initiatives in testing}

63 In the early nineties, following extensive research and preparation, language centres in German higher education came together to establish a testing, certification and accreditation system for non-specialist language learners in higher education.

64 The system, UNIcert ${ }^{\circ}$, was designed to apply across a range of languages and institutions in German higher education (AKS 1992, Voss 1996, 1997 and 2002). A unique feature of this system was that it did not impose a 'one size fits all' approach to language testing. Instead, and long before the Common European Framework of Reference, it set out to provide a common framework of reference for practically all languages taught at German universities. It was based on a consensus about general aims, an agreed system of levels of language competence and a common code of practice. It encouraged degrees of comparability in achievement across languages and institutions. But at the same time, it allowed for degrees of variation and the possibility to reflect the specific needs, aims, working modes and styles characteristic of learners at institutions of higher learning.

UNIcert ${ }^{\circ}$ stands for University Foreign Language Certification System and was established in 1991. From very modest beginnings, it developed into Germany's major accreditation agency for non-specialist language teaching. Administered by the AKS ( Arbeitskreis der Sprachenzentren), it represents the interests of all institutions and personnel involved in language teaching at university level in Germany. By July 2002, 42 academic institutions were accredited (see Voss 2002: 182) and there were many applications pending. According to figures from the same period, a total of 10,639 candidates were holders of UNIcert ${ }^{\circ}$ certificates.

Not surprisingly, UNIcert ${ }^{\circ}$ exerts considerable influence on the foreign language learning contexts throughout higher education in Germany. It provides training for staff, encourages regional co-operation, and generally provides a blueprint for similar activities designed to improve the quality of the language learning provisions made by 
universities for their (nonlanguage) students. A particular strength of this project is its commitment to continuously upgrade quality and its guidelines are periodically reviewed in the light of current experience. As Bernd Voss the current chairman of UNIcert ${ }^{\circ}$ says about it:

UNIcert ${ }^{\circ}$ has over the years of its existence made a noticeable contribution towards raising the quality and the levels of quality consciousness in a notoriously underrated fi eld, viz. the provision of high quality language learning opportunities for non-language students in Higher Education. It has provided active leadership in this field, promoting good practice and a blueprint for activity and generally improving and managing quality. It may all seem self-evident but anyone familiar with the international organisation of Higher Education in a country like Germany (and I suspect in one or two other countries as well) will agree that it is not. Short of declaring Higher Education institutions systematically unfit to provide high quality language learning environments, there is no alternative. If UNIcert ${ }^{\circ}$ didn't exist, it would have to be invented. Now. (Voss, 2002: 185)

Inevitably, UNIcert ${ }^{\circ}$ has also attracted much interest at European level. One notable example is the way in which the national association of University Language Centres in Italy are in the process of developing a similar plan for language certification in Italy. The European Confederation of Language Centres in Higher Education (Cercles) is also interested in similar activities on a European scale. It aims to gather together those with an interest in testing with a view to developing proposals for an accreditation and or certification scheme which will provide a basis for comparability of levels of assessment at European level.

\subsection{European Language Portfolio}

A second example of the contribution of language centres to the advancement of language learning is their proactive role in the development of the European Language Portfolio (ELP) for university students.

The ELP is one of the practical applications of the Common European Framework of Reference (Council for Cultural Cooperation 2001). Many of the concepts which underpin the approach to language learning in the CEF, such as learner autonomy, language awareness, levels of competence and many others, are to be found in the way in which the ELP is articulated. Its three-part structure is well known - passport, biography and dossier - and does not need to be repeated here.

The task of disseminating the ELP throughout Europe and assessing its impact on the development of language learning is now a major challenge. Pilot projects were conducted in fifteen member states and under the aegis of three international nongovernmental organisations. One of these was CercleS. Having considered the results of the pilot project at the 6th Cercles conference in Antwerp in 2000, CercleS agreed to develop its own version of the portfolio. This task was entrusted to the then President of CercleS, Professor David Little of Trinity College in Dublin who had been heavily involved in the portfolio project at the pilot stage.

71 The CercleS version of the ELP was validated by the Council of Europe in May 2002, and was formally launched at the CercleS biennial conference in Paris in September 2002. It was the first portfolio designed for university purposes and it is one of very few international portfolios which have been developed. 

CercleS portfolio is distributed electronically in PDF format which can be locally printed and photocopied. Language centres that plan to introduce the CercleS ELP will find many features that are specifically designed to support the use of the portfolio in university language teaching. The detailed goal-setting and self-assessment checklists provided in the appendix to the CercleS ELP should prove helpful in this regard. Language centres are also enabled to prepare their students to use the ELP not only by explaining the principles on which it is founded and the reporting and pedagogical functions it is designed to serve, but also by actively engaging them in the reflective practices on which effective use of the ELP depends. representative bodies of language centres are well positioned to contribute significantly to portfolio development which is likely to be a major field of interest in the years ahead.

\section{Conclusion}

In drawing this article to a close, it is useful to review the main points made so far. We have seen how language centres, from small beginnings, have enjoyed significant growth and a large following in the last thirty years. They owe their success to many factors not least the discernment, energy and commitment of their staff and a proven capacity for self-renewal. In particular we have seen how language centres have successfully navigated complex environments in a context of accelerated change and considerable uncertainty.

In this overview a number of key points emerge. This is certainly an era of great opportunity for language centres in higher education. It would appear that their time has come. But the future of language centres today is not guaranteed. To a large extent, it depends on the capacity of the members of language centres to work constructively to resolve issues of common concern, an academic commitment to developing members' expertise through applied research, and a willingness to innovate in answering the needs of Europe's university sector.

These are the goals they need to set. If they can achieve even some of them, there will be many beneficiaries. Among them the thousands of students and their teachers who work and study in language centres in higher education throughout Europe, and for whom improved and more effective language learning opportunities must remain the top priority.

\section{BIBLIOGRAPHY}

Aub-buscer, G. (ed.). 1996. The Linguistic Challenge of the New Europe. Papers from the 3rd CercleS conference. Plymouth: Cercles. 
Aub-buscer, G. and D. Bickerton. 2002. “Cercles: The first decade 1991-2000.” In M. Ruane \& G. Meijers (eds.). Language Centres: The promotion of quality in language learning, 205-216. Dublin: cercles.

AKS. 1992. "Rahmenordnung für ein institutionsübergreifendes Hochschul-fremdsprachenzertifi kat UNIcert'." In B. Favrot (ed.). Mobilität - Integration - Qualifikation: studien- und berufsbezogene Sprachausbildung an Hochschulen, 225-229. Bochum: AKS. Revised version in Fremdsprachen und Hochschule 40: 150-153.

Bickerton, D. \& M. Gotti (eds.). 1999. Language Centres: Integration through innovation.

Clarke, B.R. 1997. "Common problems and adaptive responses in the universities of the world: organising for change." Higher Education Policy 10/3-4, 291-295.

Candlin, C.N. 1998. “General editor's preface.” In P. Rea-Dickins, \& K. Germaine (eds.). Managing Evaluation and Innovation in Language Teaching: Building bridges, xiv-xxi. London: Longman.

Cormeraie, S. and K. Vogel. 1996. "Transitions culturelles et apprentissage autonome des langues étrangères." In G. Aub-buscer (ed.). The Linguistic Challenge of the New Europe. Papers from the 3rd CercleS conference, 73-97. Plymouth: CercleS.

Council for Cultural Co-operation. 2001. Common European Framework of Reference: Learning, teaching and assessment. Cambridge: Cambridge University Press.

Crystal, D. 1997. The Future of Global English. Cambridge: Cambridge University Press.

Dudley-Evans, T. and M. J. St John. 1998. Developments in English for Specific Purposes. Cambridge: Cambridge University Press.

Esch, E. 1999. “Les Centres de langues : innovation pédagogique et intégration européenne.” In D. Bickerton \& M. Gotti (eds.). Language Centres: Integration through innovation. Papers from the 5th CercleS conference, 11-30. Plymouth: CercleS.

Firth, A. \& J. Wagner. 1997. "On discourse, communication, and (some) fundamental concepts in SLA research.” Modern Language Journal 81/3, 285-300.

Fullan, M. 1998. “Linking change and assessment”. In P. Rea-Dickins \& K. Germaine (eds.). Managing Evaluation and Innovation in Language Teaching: Building bridges, 253-262. London: Longman.

Graddol, D. 1997. The Future of English? London: British Council.

Grauderg, W. 1971. The role and Structure of University Language Centres in Europe. Report CCC/ESR 71: 61. Strasbourg: Council of Europe.

Howatt, A.P.R. 1984. A History of English Language Teaching. Oxford: Oxford University Press.

Hutchinson, T. and A. Waters. 1987. English for Specific Purposes: A learning-centred approach. Cambridge: Cambridge University Press.

Hymes, D. 1974. Foundations in Sociolinguistics: An ethnographic approach. Philadelphia: University of Pennsylvania Press.

Jones, M.R. 1997. "Quo vadimus? The language centre in 2001 - an odyssey in time, space and mode." In D. Bickerton \& M. Gotti (eds.). Language Centres: Integration through innovation. Papers from the 5th CercleS conference, 113-125. Plymouth: Cercles.

Kelly, M. and D. Jones. 2003. A New Landscape for Languages. London: Nuffield Foundation. 
Little, D. 2001. "Learner autonomy and the challenge of tandem language learning via the Internet." In A. Chambers \& G. Davies (eds). ICT and Language Learning: A European Perspective, 29-38. Lisse: Swets \& Zeitlinger.

Little, D. 1999. "Presidential address at 5th CercleS conference." In CercleS Bulletin 10, 6-7. Plymouth: Cercles.

Little, D. and E. Ushioda.1998. Institution-wide Language Programmes: A research-and-development approach to their design, implementation and evaluation. London: CILT.

Little, D. and B. Voss (eds.). 1997. Language Centres: Planning for the new millennium. Papers from the 4th CercleS conference. Plymouth: CercleS.

Meyer, H.J. 1997. "Language centres and the international dimension of university life." In D. Little \& B. Voss (eds.). Language Centres: Planning for the new millennium, 3-12. Plymouth: CercleS.

Mitchell, R. 1996. "Language education and applied linguistics in a changing world." In T. Hickey \& J. Williams (eds.). Language, Education and Society in a Changing World, 7-20. Clevedon: Multilingual Matters.

Mozzon-Mcpherson, M. 2001. "Language advising: Towards a new discursive world." In M. Mozzon-McPherson \& R. Vismans (eds.). Beyond Language Teaching, Towards Language Advising, 7-22. London: CILT.

Munby, J. 1978. Communicative Syllabus Design. Cambridge: Cambridge University Press. Pennycook, A. 1994. The Cultural Politics of English as an Tnternational Language. Harlow: Longman. Perrin, M. (ed.). 1993. “Des centres de langues dans l'Enseignement supérieur: Pour quoi faire? Pour y faire quoi ?" Actes de la II rencontre de Cercles. [Available on disk.] Bordeaux: DLVP, Université Bordeaux II.

Ruane, M. 2002. “The need for a management perspective in language centre development." In M. Ruane and G. Meijers (eds.). Language Centres: The promotion of quality in language learning. Papers from the 6th CercleS conference, 177-189. Dublin: CercleS.

Van Ek, J. A. 1975. The Threshold Level. Strasbourg: Council of Europe.

Voss, B. 1996. "UNIcert ${ }^{\circledR}$ : Towards the development of a unified language certificate for German universities." In G. Aub-Buscher (ed.). The Linguistic Challenge of the New Europe. Papers from the 3rd Cercles conference, 313-332. Plymouth: CercleS.

Voss, B. 1997. "UNIcert ${ }^{\circledR}$ : The foreign language certification system for German universities." In D. Little \& B. Voss (eds.). Language Centres: Planning for the new millennium. Papers from the 3rd Cercles conference, 260-273. Plymouth: Cercles.

Voss, B. 2002. "UNIcert ${ }^{\oplus}$ : A contribution to quality assurance in foreign language training and certification programmes at German universities.” In M. Ruane \& G. Meijers (eds.). Language Centres: The promotion of quality in language learning. Papers from the 6th CercleS conference, 177-189. Dublin: Cercles.

\section{ABSTRACTS}

Expansion in the demand for language learning in the second half of the twentieth century is one of the main reasons for the growth of language centres in higher education. This article considers the past, present and future of language centres focussing on the challenges which confront them as they go forward. A brief review of language centres shows that qualities of 
pedagogic innovation, institutional adaptability and effective use of technology have contributed to their successful development to date. Success can be measured both in terms of growing numbers and outreach as language centres expand across almost all European states. However, changes in university structures and demands for language teaching continue to accelerate. Continuing success requires action and progress in key areas. These include enhancing the research profile of language centres, continuing to innovate pedagogically and organisationally and securing adequate resources. Two exemplars of successful language centre initiatives are cited: language testing and the use of the European Language Portfolio.

La progression de la demande en matière d'apprentissage des langues durant la deuxième moitié du vingtième siècle est une des principales causes de l'augmentation du nombre des centres de langues dans l'enseignement supérieur. Cet article s'intéresse au passé, au présent et à l'avenir des centres de langues, et plus particulièrement aux défis auxquels ils doivent faire face en se développant. On découvre rapidement en les étudiant que c'est parce qu'ils ont su innover sur le plan pédagogique, s'adapter au cadre institutionnel et utiliser efficacement la technologie qu'ils ont réussi à se développer. Ce succès est attesté par leur nombre et leur rôle en progression constante pratiquement partout en Europe. Pourtant, les mutations structurelles de l'université et les exigences à satisfaire sont de plus en plus nombreuses. Pour que leur succès perdure, il faut agir et progresser dans des secteurs clés. Cela veut dire renforcer la recherche, la capacité à innover sur le plan pédagogique et organisationnel, et garantir la qualité des ressources offertes. Deux exemples d'initiatives ayant donné de bons résultats dans le monde des centres de langues sont examinés : l'évaluation des compétences et l'usage du Portefeuille Européen des Langues

INDEX

Mots-clés: centre de langues, enseignement supérieur, historique, organisation, prospective Keywords: higher education, history, language centre

\section{AUTHOR}

\section{MARY RUANE}

Mary Ruane est la fondatrice et l'actuelle directrice du Centre pour les Langues appliquées de University College de Dublin, (UCD). Elle est secrétaire générale de CercleS (Confédération européenne des centres de langues de l'enseignement supérieur) après avoir été membre du Conseil exécutif de AULC (Association of University Language Centres in the UK and Ireland : Association des centres de langues universitaires du Royaume-Uni et d'Irlande). Professeur au Département d'éducation à l'UCD, sa recherche et ses publications portent sur la pédagogie de l'enseignement des langues étrangères, la politique et l'organisation de l'enseignement des langues, la technologie en lien avec l'apprentissage des langues et la formation des enseignants de langues. mary@alc.ucd.ie 